\title{
THEORY BASIS OF EDUCATIONAL COGNITION
}

\section{SUMMARY}

Introduction. The modern society develops rapidly, and constantly significant changes take place in economics, politics, social processes. The processes of changes leave behind schools, education, upbringing, and neither society, nor personality needs, nor individual potential improvement at school is satisfied.

Aim of the Study. To analyse the unity of didactics, pedagogical psychology and methods as the theory basis of pupils' educational cognition.

Materials and Methods. Pedagogy history, didactics, pedagogic psychology and method sources in Latvian, European and Russian pedagogy and psychology were used for the scientific analysis. Results. Theories of didactics have been perfected within the historic development of school and pedagogic thought. Methodology principles of conformity of nature and culture that require basing pupils' cognition on peculiarities of the specific age and development in studies are significant.

Conclusions. Results of the scientific analysis prove that training should use didactic theories, actual findings of pedagogical psychology that correspond to the period, and methods of each lesson should be based on that for the specific age of pupils. General didactics theories are not sufficient for the school.

Key words: didactics, pedagogical psychology, methods

\section{INTRODUCTION}

It should be noted that history of civilisation has never had so much public discussions on school education as in the previous 50 years. This can be explained by the fact that the society develops rapidly and significant changes in economics, politics, and social processes take place without stopping, but the school, education as a whole is left behind the needs of a personality and the society. Requirements for development of human resources have become global, and they are based on education. Results in education cannot be achieved at once; they are an investment into the future. Furthermore, quite a few theories have existed on education and science as a nonproduction branch of national economy. This is noticed even today in the activities of many countries, especially of politicians and financiers that money is granted for development of education, culture and science according to the principle of leftovers. This is characteristic also of the development of the independent state of Latvia. Today, we can responsibly state that education, science, culture become a prominent force of society development that directly affects production. Thus education and science has components of production forces. Following and analysing the development of Olaine College of Mechanics and Technology for a longer period of time, it can be stated that one condition for development of this educational institution is cooperation with production enterprises. Influence of joint stock company "Grindeks" and "Severstallat" on study process at the college should be highly appreciated. A/s "Grindeks" human resources department manager Dace Šaitere and a/s "Severstallat" personnel and quality director Artūrs Graudiņš are 
own people at the college and they feel being responsible for development of the material basis and the pedagogical process. Artūrs Graudinšs is also LU doctoral student. In the 21 st century, drawing closer of production, and education, and science is an objective process.

\section{AIM OF THE STUDY}

To analyse the unity of didactics, pedagogical psychology and methods as the theory basis of pupils' educational cognition.

\section{MATERIALS AND METHODS}

Didactics - theoretical basis for studies

In order to be clearly aware of the objective direction of education development and to determine reasonable goals for education in the whole 21 st century, it is important to analyse problems of didactics and methods in theory and practice of pedagogy. Basis for development of study process is didactics and its actual theories.

Didactics (from Greek Didaktikos - instructive) is a part of the general pedagogy which develops the theory of studies - teaching and learning. In 1623, Francis Bacon (1561-1626) separated pedagogy in the system of sciences as an independent science (Бекон, 1977). Only nine years passed, and Czech scientist John Amos Comenius (Jan Amos Komenský) (1592-1670) wrote the first capital work in pedagogy Didactica Magna in 1632 in the Czech language, in 1657, in the Latin language, and in 1992, it was published also in the Latvian language (Komenskis, 1992). John Amos Comenius formulated the basic principles in didactics which are determined by the essence of study process, its aim and development of children.

In the first half of the 19th century, didactics as a special study theory in pedagogy rapidly develops in Germany. In 1834-1835, A. Diesterweg (1790-1866) forms a didactics as uniform study theory, acquired both by teachers and high school students. A. Diesterweg makes alive the idea of development in studies. A child constantly changes and likewise develops his psyche. Overcoming study contradictions, the child's development takes place. Therefore Diesterweg brought forward the idea of the main function of lessons - to develop the child. Diesterweg established methodology principles of cultural and natural conformity in studies. He acknowledges that a child must be taught and brought up in compliance with his nature and level of cultural environment (Дистервег, 1913).

Adolf Diesterweg's idea on the principle of cultural correspondence in pedagogy agrees with the principle of cultural correspondence in psychology by Lev Vigotsky (1896-1934) (Выготский, 1991).

In Russia, one of the first to establish didactics is Konstantin Ushinsky (1824-1870). His work Human as a Subject of Education summarises ideas that were known in physiology, psychology and pedagogy in the 19th century. He has left findings on further formation of developmental studies. Clearness in studies corresponds to a child's nature according to K. Ushinsky. A child thinks in colours, sounds, that is, by senses. Therefore, for a system of knowledge to be formed in one's mind, the child's senses should be developed according to K. Ushinsky (Ušinskis, 1980).

In Latvia, findings of progressive didactics in the 19th and 20th century are implemented by teachers who got their knowledge in universities of Berlin, Tübingen, Frankfurt, Dorpat (now Tartu), Petersburg and others.

The scientific heritage of Eduards Pētersons has a lasting significance in didactics. He has formed a study work theory for Latvian teachers (Pētersons, 1931).

The philosophical basis of didactics is formed by a study on cognition, on cognition processes 
of children and adults. The approach of entirety to a child in organising cognition processes - in his physical, mental and social balanced development - is very special.

Contents of didactics is formed by understanding of didactics as a part of pedagogy science, laws of study process, contents, principles, study methods and forms.

Historically didactics has developed into many nowadays valuable study theories. German pedagogues have prepared a scientific-theory map where four paradigms are clearly reflected: 1 ) dialectic, 2) hermeneutic, 3) constructive and 4) empiric-analytical that facilitates development of pedagogy, especially didactics. Each paradigm has its leading didactic approaches, for example, activities of personality, humane-pedagogic, critically constructive didactics, learning theory didactics and others approaches which are well known to Latvian pedagogues (Meyer, 1994).

The English school is based on theory of improving intelligences developed by psychology professor Howard Gardner of the Harvard University. Gardner reveals that all people are able to master the world by using the seven intelligences: verbal/linguistic, logical/mathematical analysis, visual/spatial concepts, musical/rhythmic thinking, interpersonal understanding, intrapersonal understanding and bodily/kinaesthetic use cognition. (Gardner, 1996). In 1999 H. Gardner (Gardner, 1999) added two more intelligences: naturalist and existentialist. It is important that a pupil actualises and combines those types of abilities at a lesson. Exactly the productivity in developing the abilities in each pupil, is the challenge to the pedagogical process in the activities of each teacher.

H. Gardner has proven that each individual has a set of these mental abilities and each pupil should learn to reveal and develop one's abilities during the school's pedagogical process in order to fully participate in a life-activity of democratic society. H. Gardner is of the opinion that the styles of pupils' learning and teachers' teaching can be coordinated by purposeful use of information technologies that have been adapted to various cultural roots of pupils' culture; however, it is difficult to change the results. The pupil's internal psychic nucleus, the mental abilities must be found. Gardner's approach to abilities is based on pedagogical psychology that provided many a new knowledge on learning children, youth up to the 21 st century (Gardner, 1996).

Based on development of didactics, the pedagogical psychology began to form naturally. It is a sub-branch of psychology studying the psychic foundation of human learning and upbringing problems. The theory basis of psychology for facilitating development of children has become pragmatic in activities of each teacher. The pedagogic psychology in unity of physiology of higher nerve activity, development psychology forms a significant pedagogical approach. Psychological facts on peculiarities of children and youth development, regularities on processes of psyche in studies in various ages, on social and cultural environment provide pedagogues an opportunity to form more precise study methods. The contents of pedagogy books in the end of the 19th century and beginning of the 20th century form the psychological basis of studies and upbringing. For example, General Pedagogy by I. Skvorcov issued in 1910 in Saint-Petersburg contains "Attention". Circumstances that facilitate attention. Cause of inattentiveness. Development of children's attention... Concepts... Memory... Imagination... Thinking.. Language.. Feeling... Will... Awareness and self-awareness. "As a source of psychology and pedagogy sciences, this book finds self-observance and observance skills that provide understanding of the mental state - hate, joy, sadness and the like. The author is of the opinion that a teacher must definitely be a self-observer, that is, to become a self-observance subject and be able to observe others, especially his pupils. The author includes these teacher's skills into the structure of pedagogical talent. Thus, teachers' 
diaries were formed and served as significant sources for didactics and pedagogical psychology (Скворцовъ, 1910).

The pedagogical psychology is a science that helps a teacher to form understanding on unity of didactics and methods. For example, teachers acknowledge the individual teaching style, but still teach mainly frontally. This is one of reasons for low teaching motivation, poor results.

According to Gardner, each topic in a lesson may have at least 5 approaches, wherefrom a pupil finds the most appropriate one for his mental skills notices it and becomes keen to learn. This means that a pupil has this approach neither too easy, nor too difficult, and he is interested in studies. H. Gardner enlists the 5 developed approaches in acquisition of learning programmes: 1) narrative, 2) logically quantitative, 3) fundamental or philosophical, 4) aesthetic and 5) based on pupil's experience.

A. Barbers writes about the didactic theory as basis for learning process at school: "If we wish to form a school program having motivating potential and providing all young people with success in studies, we must fully acknowledge the significance of Gardner's idea on Multiple intelligences and learning styles," as indicated in his book Teaching Game: Arguments in Favour of Educational Revolution (Barbers, 2007, 191).

Besides teaching process acquisition theories, in modern didactics a lesson system of learning organisation gains a new sounding. Foundation for this learning organisation was made by John Amos Comenius in the 17th century and it has been preserved with some slight variants up to nowadays. In the beginning of the 20th century, John Dewey introduced "laboratory method" in order to individualise learning at school. Likewise Dalton's plan was spread by neither of these methods received a long and permanent place in school activities. In 1931, in part II New Methods in Latvian Schools ("Jaunās metodes Latvijas skolās") of Nature Study Methods ("Dabas mācības metodika"), G. Sergis analyses also the place of Dalton's plan and possibilities to use it in Latvia. A. Karlivāns shares his experience in use of elements of Dalton's plan in elementary school. In Latvia, nowadays still well-known teacher-experimenter writes on pupil's report in studies. Until now, useful findings are expressed by teacher J. Mežsēta on evaluation of results in nature studies (Nature Study Methods, 1931). System of lessons at the classroom is convenient for the teacher but not for the pupil. When socialisation processes become especially active in schools, by organising small-group work, pair-work, research work in projects, the role of the system of lessons is decreased in education. Pupils have little possibilities to learn from each other and the most important object, to which a pupil's look is directed, is the back of the head of the pupil sitting in front of him. Teachers facilitate preservation of this kind of work organisation because the frontal work can be clearly managed. How to individualise pupil's creative and independent activities for development of his learning skills, sense-full learning at acquisition of skills of lifeactivities or competencies, how to improve one's self-experience in everyday life. These issues are theoretically solvable not only on the basis didactics, but also on the basis of theories of pedagogical psychology in the body of each school. At first, classrooms must be reorganised so that pupils could contact each other both verbally and non-verbally. For quite a time, didacts have proved that one of best methods of teaching is "a pupil teaches a pupil" because in such a manner the success of best pupils at studies are strengthened and they give their contribution to studies by cooperating with peers. Those are the issues of didactics, pedagogical psychology, methods - how to organise cooperation in a live triangle - teacher, pupil, parents, how to organise mutual learning among pupils, what is the efficiency of mutual learning cooperation, how pupils' attitude towards 
school and towards each other, parents and studies in whole is formed. Without possibilities to prove oneself, express oneself in everyday's studies, development of a pupil's skills cannot be imagined. Schools must undertake a new aim, namely, facilitation of development of learning competence which is the ability to manage one's own learning, writes Elīna Maslo (Maslo, 2003, 44). How to reach this goal in school's everyday work, will be decided by teaching methods.

\section{Teaching and learning methods}

Methods is a branch of pedagogy - study of a set of methods that ensure purposeful process of teaching and upbringing pupils and adults. Methods is applied didactics. It explains use of didactic laws and norms at studies.

In a school's work, methods of each learning subject is important that develop rules for learning specific subjects on the basis of actual didactic theories and that correspond to specific regulations of pupils' development. If didactics is based on general pedagogy theory, then the theory basis of a study subject methods on the one hand by didactics, pedagogical psychology and on the other hand by science rules corresponding to the study subject. Pieces of information on methods come from the 18th, the 19th centuries when schools begun to differentiate subjects. Methods deal with preparation of programs and text-books that are suitable to the contents, organising and evaluating learning process, development of efficient learning methods. General laws of didactics were not sufficient for solving these tasks, methods of subjects was necessary.

Likewise now, problems of methods is tasks, structure of study subject, mutual contacts between study subjects, development of programs, text-books that determine "how to teach?" and "how to learn?" a subject. So far, methods were mainly governed by the approach "how to teach?" When transferring to co-operational pedagogy, besides "how to teach?" the problem "hot to learn?" is very significant.

One of the actual problems of methods is - what is more important in studies - "process" or "result". In England, these discussions were public for a long time in the 80s of the 20th century.

Defenders of the "process" considered children and youth steps used for learning something as most important in learning process. As a result of this, requirements were established to grant priority to learning skills, but less attention to the acquired facts.

Defenders of the "result" had the opposite opinion: it is not important how one learns, the main thing is what one has learnt. Supporters of this opinion had everything expressed in the goal.

In 1998, the national school program introduced in England, facilitated silencing of these discussions because it was announced that the most important aspect in learning is "process" as well as the "result" (Барбер, 2007).

Likewise our schools care about good results, fight for a larger amount of winners at pupil competitions, but not always we are aware of what motives lead and what is the procedural approach of these pupils to studies. So, we often stress result in pupils' studies. There are, however, schools that carefully work to implement dialogic approach to lessons (Amata Elementary School of Cēsis district). Pupils learn to answer questions, make questions rather less, develop abilities to discuss - express and defend one's opinion (Kalnciema Secondary School of Riga district), constantly conclude based on facts, and to argument. Development of reasoning skills forms the nucleus of pupils' thinking. Product of the teacher's work should be characterised to a large extent by development of pupils' thinking skills and satisfaction of cognition needs.

Do pupils hear much less conclusions of a teacher, facts about nature, society and man that a pupil should learn? This is the problem of methods of each school - how to develop an 
independent, creative learning activity. Its aim is to provide a pupil with the opportunity to become aware of his learning and development potential, to integrate new knowledge in his activities and reveal to others what he is able to (Maslo, 2003, 158).

A pupil's ability to self-evaluate his learning process and result cannot be left without attention. Pupils should be taught to evaluate their own work already in the first grade (Hahele, 2006; Praulīte, 2008).

\section{RESULTS}

Theories of didactics have been perfected within the historic development of school and pedagogic thought. Methodology principles of conformity of nature and culture that require basing the pupils' cognition on peculiarities of the specific age and development in studies are significant. Pedagogical psychology as a science requires teachers to structure conformity of study contents and form to the specific level of pupils' development. This means that for each lesson, the teacher chooses such study methods so that pupils were interested in studying and the cooperation would be productive.

Learning as students' professional activity builds the foundation for balanced physical, mental and social development of their personality.

A teacher as an organiser of the process of learning cognition helps the student to understand his/her "I".

Students" understanding of these inter-coherences "Man" $\leftrightarrow$ "Nature" $\leftrightarrow$ "Society" forms on scientific basis in every lesson, in every step of students' cognitive process.

Teachers' creative integration of conclusions of 1) didactics, 2) psychology of development, and 3) methods in organising the students' learning process is the scientific basis which stimulates students to find out the world as a unity and to be conscious of him/her as a component of this unity.

\section{CONCLUSIONS}

Thus the modern methods, which is based on actual didactics theories and pedagogical psychology findings on learning competencies of children and youth, improvement of their self-experience in compliance with the specifics of individual development, should reply to the following: how pupils may learn in a more interesting and productive manner. A reply can be searched by each teacher in the unity of didactics, pedagogical psychology and methods.

Integration of these scientific conclusions provides safe theoretical basis for the teacher in organisation of the cognitive process of learning so that the students could find out the world in inter-coherences of "I" $\leftrightarrow$ "Nature" $\leftrightarrow$ "Society".

\section{REFERENCES}

1. Dabas mācības metodika (1931) [Nature Study Methods]. Group of authors. (Eds.) J. Ģirupnieks. Rīga: Valters un Rapa, 382 lpp. (in Latvian).

2. Gardner, H. (1996) Der ungeschulte Kopf. Wie Kinder denken [Untrained Head. How Children Think]. Stuttgart: Klett-Cotta, S. 371 (in German).

3. Gardner, H. (1999) Intelligence Reframe: Multiple Intelligences for the 21st Century. New York: Basic Books, $292 \mathrm{p}$.

4. Hahele, R. (2006) Pašnovērtējums mācību procesāa [Self-Evaluation in Learning Process]. Rīga: Raka, 222 lpp. (in Latvian). 
5. Komenskis, J. A. (1992) Lielā didaktika [Didactica Magna]. Rīga: Raka, 232 lpp. (in Latvian).

6. Maslo, E. (2003) Mācīšanās spēju pilnveide [Development of Learning Skills]. Rīga: Raka, 193 lpp. (in Latvian).

7. Meyer, H. (1994) Unterrichts Methoden [Class Methods]. Theorieband, II: Praxisband, 6. Auflage, Frankfurt am Main, 272 S. (in German).

8. Pētersons, E. (1931) Vispārīgā didaktika [General Didactics]. Rīga: A. Gulbis Publishing house, 125 lpp. (in Latvian).

9. Praulīte, G. (2008) Bioloǵijas mācību metodika [Methods of Biology Learning]. Rīga: Raka, 223 lpp. (in Latvian).

10. Ušinskis, K. (1980) Pedagogisko rakstu izlase [Selection of Pedagogic Articles]. Rīga: Zvaigzne, 229 lpp. (in Latvian).

11. Барбер, М. (2007) Обучающая игра: аргументы в пользу револючии в образования [Теaching Game: Arguments in Favour of Educational Revolution]. Москва: Просвещение, 349 с. (in Russian).

12. Бекон, Ф. (1977) Сочинения в двух томах [Compositions in Two Volumes]. Volume 1. AH CCCP. Москва: Мысль, 590 с. (in Russian).

13. Выготский, Л. С. (1991) Педагогическая психология [Pedagogical Psychology]. Москва: Педагогика, 536 с. (in Russian).

14. Дистервег, А. (1913) Руководство для немецких учителей [Guidance for German Teachers]. In: Дистервег А. (1956) Избранные педагогические сочинения [Collected Articles of Pedagogy]. Москва: Учпедгиз, с. 136-203 (in Russian).

15. Скворцовъ,И. В.(1910) Общаяпедагогика [General Pedagogy]. Санкт-Петербург:БР. Башмаковых. 204 c. (in Russian).

Prof. Dr. habil. paed. Ausma Špona

Riga Teacher Training and Educational Management Academy, Scientific Institute of Pedagogy

Address: Imantas 7.līnija 1, Rīga, LV-1083

Phone.: +371 26464489

E-mail: ausma@lanet.lv 